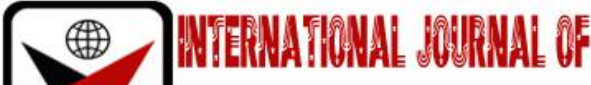

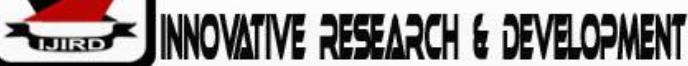

ISSN 2278-0211 (Online)

\section{Leadership and Management Challenges of Heads and Teachers in School Administration: A Case Study of Ghana Education Service Kumasi Metropolis}

\author{
Ayikue M A \\ Lecturer, Department of Educational Leadership, College of Technology Education, \\ University of Education, Winneba, (COLTEK), Kumasi, Ghana
}

\begin{abstract}
:
The purpose of the study was to assess the leadership and management challenges in the Ghana Educational Service. Quantitative research approach was used for the study. The population for the study was one hundred and forty comprising 43 head teachers and 97 teachers selected from the Ghana Education Service Kumasi Metropolis. Census method was used to select all the 140 respondents for the study. Questionnaire was the main instrument used to collect primary data. The statistical package for social scientists (SPSS version 20) was used to analyse all the responses from the questionnaire. The study results concluded the leadership and management challenges faced by heads and teachers in school administration were: recruitment challenges and inadequate teachers, in-service training challenges, financial constraint, workload for teachers who must continue with other assigned duties, inadequate time to offer a comprehensive in-service training programmes, and inadequate skill and knowledge by teachers affects teaching and learning. The study results recommended that the Government of Ghana through the Ghana Education Service (GES) should provide adequate financial and logistics to the various schools in the study area to enhance the head teacher's leadership and managerial work.
\end{abstract}

Keywords: Leadership, management, heads, teachers, and administration

\section{Introduction}

School leadership and management are dynamic mind-sets and cultures in an educational organisation that influences the success of both students and staff. This set of attitudes drives innovation, personality, and relationships. Leadership is about fundamental discrepancies or uniqueness relationships (Edwards, 2015). Leadership is seen as the performance of leaders to persuade their subordinate to perform unusual task that become the center of change, principles development and transition, and shared dreams are recognized (Kouzes \& Posner, 2012). Therefore, school leadership and management should be successful in achieving productivity and outcomes. School leadership not manage resourcefully can distort administrative resources, regulators, school community, group work, and a numerous of renovation functioning for heads, teachers and students.

According to Bush and Glover (2014), the concept of governance in school takes a different connotation of education administration to educational organization and can be equate to what is called academic leadership. In the activities of such terminologies there are differences: administration, management, and leadership. School leadership is critical in the Ghana Education Service (GES). There exist a vast space among quantity and quality of education in the country since quality education goes beyond just the provision of infrastructure (Oduro, 2008). In light of this, stakeholders are looking for other avenues for solutions to the current challenges. One of such areas attention is being drawn to the role played by heads and teachers in the delivery of instruction and learning quality results in educational system in the Ghana (Oduro, 2008).

Heads and teachers in the educational system have predominant task of accomplishing of schools' objectives, schedules, and policies that increases achievements to the schools outcomes (Hopkins and Jackson, 2003). According to Oduro(2008),numerous policies ranging from local, national to international have not produced the expected results because it seems that those tasked to implement the policies of government in the schools lack the knowledge, skills and competencies to manage the schools.

However, the request to increased education delivery has developed as a result of added primary accomplishment percentages. As accessibility in school percentages strengthen and preserving rates progress, some countries including Ghana are facing massive societal request for broader methods to higher results driven education (Alvarez, Gillies \& Bradsher, 2003). The high demand for teachers in the high schools coupled with the budgetary constraints has petition the authorities to look for operative and proficient styles to employing, organising, accompanying, and maintaining competent school educators and heads (Mulkeen, Chapman, DeJaeghere, \& Leu, 2007). 
Educational system as pointed by Afful-Broni (2014), should be characterized by fervent competition, strategic, and transformational. As noted by Kadingdi (2016), Ghana public schools should move from the failure to achieve reliable learning results at all levels. In order to transform school in yielding a positive outcome the leaders should be empowered with leadership skills and logistics. But these professionals who carry out all these meaningful work are faced with challenges in regards to their work, training, education, and continuous professional development(Preble, 2014). In most public schools today, noted by Preble, teachers are overwhelmed with the huge number of students. Ghana is not left out either, as most teachers especially those in the public schools struggle with huge numbers of students, overwhelming duty schedules, inadequate teaching and learning aids with very little prospects of training and development (Inkoom, 2012).

\subsection{Head teacher's Leadership Patterns on the Development of Effective Administration in Schools}

Hallinger and Heck (2010), argued that numerous researchers have studies over time, some of these studies have outlined leadership in the sense of school effectiveness and better schools as an engine of change. Leadership is the mechanism through which a person influences another person or group member with no pressure or intimidation in setting goals and attracting them (Greenberg and Baron, 2013). School leaders achieve goals by energetic and enthusiastic superior figures - shown their enthusiasm, ideas and leadership and sensational about challenging the status quo and in seeking successful equally lasting results to governance problems (Fry (2013). Also, Cronje, Du Toit, Marais and Motlatla (2014,) describe leadership as an important managerial role, which is to orientate the actions of others in order to achieve predetermined objectives. School leadership some academics say it is a subtitle term that needs to be divided into five levels and sub-divided into components. These levels are: entity, organizational, culture, society, and global. The sub- component includes: economic, financial, political, and cultural as well as education (Saleem, 2010).

Positive results yielding schools have common features that distinguished them from the low performing schools. Schools are well ordered, school undertakings are properly designed and, persons who run these schools have a counseling, proactive plan and have a clear vision (Covey, 2012). According to Raynolds (2016), some of the factors that contribute to the schools efficiency are that of the distinct conduct of the teachers and the heads. Such factors are: precision of problems, high outlook, dedication to standard achievement and the structures of the teaching efficiency (Hopkins and Jackson, 2003).

\subsection{Management and School Effectiveness}

Managing effective school in developing countries has seldom been studied and effective school factors have been investigated three or four times in over 100 studies (Guoxing, 2007). Previous studies on school performance leadership and management have therefore been documented in fragmentary forms (Bottery, 2001). Most studies failed to acknowledge the multilevel nature of the effects of academic performance (i.e. students, teachers, colleges, and district and state). It is, equally obvious that efforts in Sub-Saharan African countries to provide successful schooling should be specific to their backgrounds, nationwide values and different local circumstances in Africa (Guoxing, 2007). Consequently, to investigate research studies in Sub-Saharan environments into school performance, so that features which are different in encouraging successful education in specific (Creemers \& Kyriakides, 2016). Scheerens' (2009), screenings showed a modest effect of resource involvement, school organizational features and average size on academic environments on research findings from established and emerging countries and the results indicated overall. Furthermore, it was discovered that the input-process is prevalent in developing countries, as far as the efficacy of the schools is concerned. The study of school effectiveness in some developing countries indicated a higher frequency of managerial variables. In addition, Adewuyi's (2008) study on the efficiency of schools and the certification of English in Nigeria reveals support for many of the school effectiveness features as demonstrated in the literature; strong and targeted school management, clearly stated goals, vital expectations in the performance of students and so on. In some schools, the extra-mural lessons seemed to be relevant, although they did not have a successful examination results.

\subsection{The Head Teacher's Authority and School Effectiveness}

Smith and Cronje (2012) claim that any manager who safeguards that the assistants collaborates to accomplish their goals specified by the company (school), regardless of their level of management is also sometimes a chief. Authority has the component of the manager's right to enact certain steps under explicit orders (policies) and to take action against individuals who do not comply in achieving those goals. It can be concluded from the above that authority has to do with leadership. The school head is allowed to impose his/her authority within the school (Hatcher, 2005). The idea of distinction between authority and power is therefore important to understand. The authors, Gerber, Nel and Van Dyk (1998), claimed most individuals have influence (which has to be given), but they do not have the control (which is the acquisition aspect) to effectively claim influence.

\subsection{Meaning of Power in Schools}

Subordinates empower a leader or manager to control them and performance, because they (leaders) should have some kind of authority to be considered rulers. They should exercise power. Said differently, control (the ability to influence others ' behavior) has nothing to do, or is not gained in an organization, together with a name or work description (e.g. school) with the hierarchical role of an educator; however, the leader should receive it (Smith and Cronje, 2012)

\subsubsection{Expert Power}

This is knowledge dependent perception. A head in this category of control has the knowledge and expertise required. Expert influence is an important element of learning. For example, this is why students rely on their teachers ' 
superior knowledge and experience. Expert capacity, for example, means an educator, a solicitor, an inspector, a doctor, etc. All these experts are valued because of their experience and know-how. It is not enough for the school leaders to have certain powers and authority. Leaders need to use leadership powers and influence to safeguard a successful work excellence in the class, but heads also need to know that people have tasks to complete. The activities of employees in a school environment are driven by good management, with important relationships, enjoyment and satisfaction at work. In other words, a leader in education must balance a task-oriented with a personal leadership-oriented.

\section{Methodology}

The study was to assess leadership and management challenges in the Ghana Educational Service. The study employed quantitative research approach. The population for the study was one hundred and forty comprising 43 head teachers and 97 teachers selected from the Ghana Education Service Kumasi Metropolis. Census method was employed to select all the 140 respondents for the study. Questionnaire was the main instrument used to collect primary data. The statistical package for social scientists (SPSS version 20) was used to analyse the responses from the questionnaire.

\section{Results and Discussions}

\begin{tabular}{|c|c|c|c|c|c|c|c|c|}
\hline Statement(s) & Cat & 1 & 2 & 3 & 4 & 5 & $\begin{array}{c}\text { Mean } \\
\mathrm{X}\end{array}$ & Rank \\
\hline $\begin{array}{c}\text { Head teachers face recruitment } \\
\text { challenges and inadequate } \\
\text { teachers }\end{array}$ & $\begin{array}{c}\mathrm{HT} \\
\mathrm{T}\end{array}$ & $\begin{array}{l}0 \\
0\end{array}$ & $\begin{array}{l}0 \\
0\end{array}$ & $\begin{array}{l}5 \\
5\end{array}$ & $\begin{array}{l}29 \\
69\end{array}$ & $\begin{array}{c}9 \\
23\end{array}$ & 3.21 & $1^{\text {st }}$ \\
\hline $\begin{array}{l}\text { Head teachers encounter in- } \\
\text { service training challenges }\end{array}$ & $\begin{array}{c}\mathrm{HT} \\
\mathrm{T}\end{array}$ & $\begin{array}{l}0 \\
0\end{array}$ & $\begin{array}{l}0 \\
0\end{array}$ & $\begin{array}{l}8 \\
6\end{array}$ & $\begin{array}{c}23 \\
7\end{array}$ & $\begin{array}{l}12 \\
84\end{array}$ & 3.18 & $2^{\text {nd }}$ \\
\hline Financial constraints & $\begin{array}{c}\mathrm{HT} \\
\mathrm{T}\end{array}$ & $\begin{array}{l}0 \\
0\end{array}$ & $\begin{array}{l}0 \\
0\end{array}$ & $\begin{array}{c}5 \\
11\end{array}$ & $\begin{array}{l}22 \\
28\end{array}$ & $\begin{array}{l}16 \\
68\end{array}$ & 3.15 & $3^{\text {rd }}$ \\
\hline $\begin{array}{c}\text { Head teachers face work } \\
\text { overload for teachers who must } \\
\text { continue with other assigned } \\
\text { duties }\end{array}$ & $\begin{array}{c}\mathrm{HT} \\
\mathrm{T}\end{array}$ & $\begin{array}{l}0 \\
0\end{array}$ & $\begin{array}{l}0 \\
0\end{array}$ & $\begin{array}{l}4 \\
3\end{array}$ & $\begin{array}{l}25 \\
12\end{array}$ & $\begin{array}{l}14 \\
82\end{array}$ & 3.04 & $4^{\text {th }}$ \\
\hline $\begin{array}{l}\text { Inadequate time to offer a } \\
\text { comprehensive in-service } \\
\text { training programmes }\end{array}$ & $\begin{array}{c}\mathrm{HT} \\
\mathrm{T}\end{array}$ & $\begin{array}{l}0 \\
0\end{array}$ & $\begin{array}{l}0 \\
0\end{array}$ & $\begin{array}{l}4 \\
5\end{array}$ & $\begin{array}{l}24 \\
19\end{array}$ & $\begin{array}{l}15 \\
73\end{array}$ & 2.96 & $5^{\text {th }}$ \\
\hline $\begin{array}{c}\text { Inadequate skill and knowledge } \\
\text { by teachers affect teaching and } \\
\text { learning }\end{array}$ & $\begin{array}{c}\mathrm{HT} \\
\mathrm{T}\end{array}$ & $\begin{array}{l}0 \\
0\end{array}$ & $\begin{array}{l}0 \\
0\end{array}$ & $\begin{array}{l}6 \\
6\end{array}$ & $\begin{array}{l}19 \\
21\end{array}$ & $\begin{array}{l}12 \\
70\end{array}$ & 2.72 & $6^{\text {th }}$ \\
\hline $\begin{array}{c}\text { Poor work and living } \\
\text { environment affect head teachers }\end{array}$ & $\begin{array}{c}\mathrm{HT} \\
\mathrm{T}\end{array}$ & $\begin{array}{l}0 \\
0\end{array}$ & $\begin{array}{l}5 \\
0\end{array}$ & $\begin{array}{l}7 \\
8\end{array}$ & $\begin{array}{l}17 \\
24\end{array}$ & $\begin{array}{l}14 \\
65\end{array}$ & 2.69 & $7^{\text {th }}$ \\
\hline $\begin{array}{c}\text { Inadequate motivational } \\
\text { challenges affect head teachers } \\
\text { and teachers }\end{array}$ & $\begin{array}{c}\mathrm{HT} \\
\mathrm{T}\end{array}$ & $\begin{array}{l}0 \\
0\end{array}$ & $\begin{array}{l}5 \\
0\end{array}$ & $\begin{array}{l}6 \\
4\end{array}$ & $\begin{array}{l}17 \\
18\end{array}$ & $\begin{array}{l}15 \\
75\end{array}$ & 2.38 & $8^{\text {th }}$ \\
\hline Average Total & HT & & 10 & 45 & 176 & 121 & & \\
\hline Average Percent (\%) & & & 2.8 & 12.8 & 50 & 34.4 & & \\
\hline Average Total & $\mathrm{T}$ & & 0 & 48 & 198 & 540 & & \\
\hline Average Percent (\%) & & & 0 & 6.1 & 25.2 & 68.7 & & \\
\hline
\end{tabular}

Table 1: The Leadership and Management Challenges Faced by Head Teachers in School Administration Strongly Disagree = 1; Disagree = 2; Undecided= 3; Agree = 4; Strongly Agree = 5

Cat - Category, HT-Head Teachers, T- Teachers

The study results indicate that an average of $50 \%$ of the head teachers agreed compared to $68.7 \%$ teachers intensely agreed that the leadership and management challenges encountered by head teachers in school administration were rated as recruitment challenges and inadequate teachers (mean score - 3.21, ranked 1st), in-service training (INSET) challenges (mean score - 3.18, ranked 2nd). Financial constraint (mean score - 3.15, ranked 3rd), work overload for teachers who must continue with other assigned duties (mean score - 3.04, ranked $4^{\text {th }}$ ), Fullan (2011), also recognizes that INSETs usually fail and in only a very small minority, follow-up assistance to concepts and realistic solutions implemented in inservice programs occurs. In Ghana, there tends to be few follow-up reviews and INSET services rarely address the needs and concerns of individuals.

Inadequate time to offer a comprehensive in-service training programmes (mean score -2.96 , ranked $5^{\text {th }}$ ), inadequate skill and knowledge by teachers affects teaching and learning (mean score - 2.72, ranked $6^{\text {th }}$ ). The point of departure for every in-service training and development, according to Morrant (2011), is to meet the professional requirements of teachers. Furthermore, since education is an incredibly difficult and complex operation, and the conditions are changing constantly, problems in individual schools and classrooms are eventually emerging. The teachers 
who are most involved are better able to diagnose these issues because they only know the students and the background well enough. Therefore, INSET practices should be closely tailored to address and overcome these issues (Morrant, 2011).

Poor working and living environment affects head teachers (mean score - 2.69, ranked $7^{\text {th }}$ ), and inadequate motivational challenges affects head teachers and teachers (mean score - 2.38, ranked $8^{\text {th }}$ ). Newton (2008) has shown that, too often, the needs of teachers (whether personal needs or those resulting from their school environment), vary from the content of the courses. The findings show that teachers are too often divergent. The problem is partly due to insufficient interpretation or comprehension by course organizers, partly due to insufficient knowledge about content of course and partly due to the unsystematic manner in which teachers choose courses. The outcomes of the course are very difficult to understand. The heterogeneous composition of the course was also a result. Where an assumption was not made that the learners might possibly benefit from a course, they could not always employ new knowledge and skills learned during the course because, whether for reasons of statuses, lack of funds, lack of appropriate feedback mechanisms from the course to school or a combination of such issues, they could not influence what was happening in their schools. One of the major challenges has been the financing of INSET programmes.

\section{Conclusions and Recommendations}

The study results concluded the leadership and management challenges faced by head teachers in school administration were recruitment challenges and inadequate teachers, in-service training challenges, financial constraint, work overload for teachers who must continue with other assigned duties, inadequate time to offer a comprehensive inservice training programmers, inadequate skill and knowledge by teachers affects teaching and learning, poor working and living environment affects head teachers, and inadequate motivational challenges affects head teachers and teachers. A worthy mixture of management and leadership skills will enable a school leader to accomplish the school's priorities and objectives through dedicated and qualified educators who has comparable desire and foresight for excellence learning.

The study recommended that the Government of Ghana through the Ghana Education Service (GES) should provide adequate financial and logistics to the various schools in the country to enhance the head teacher's leadership and managerial work. Also, the Government of Ghana through GES Kumasi Metropolis, periodically organize in-service training on leadership and management seminars for school heads and teachers to equip them with the skills needed for school improvement. The GES directorate Kumasi Metropolis should appeal to the Government of Ghana through the Ghana Education Service (GES) to recruitment more professional teachers to reduce recruitment issues for effective learning outcomes.

\section{References}

i. Adewuyi, D. A. (2008). Understanding School Effectiveness and English Language Certification in the Third World: An Ethnographic study of some Nigerian secondary schools. Unpublished thesis, Department of Language Studies, Faculty of Education University of British Columbia, Canada.

ii. Afful-Broni, A. (2014). Theory and practice of educational leadership in Ghana. Accra: Yamens Press Ltd.

iii. Alvarez, B, Gillies, J. \& Bradsher, M (2003). Beyond basic education: Secondary education in the developing World. Washington, D.C.: World Bank Institute and Academy for Educational Development.

iv. Baron, A. R. \& Greenberg, J. (2013). Organizational Behaviour in Organization. Understanding and managing the human side of work. Canada: Prentice Hall.

v. Bottery, M. (2001) Globalisation and the UK competition state: no room for

vi. Transformational leadership in education? School Leadership and Management, 21(2), 199-218.

vii. Bush, T. \& Glover, D. (2014). School leadership: Concepts and evidence. Nottingham: National College for School Leadership.

viii. Covey, S. (2012). Principled-centered leadership. NY: Simon and Scuster.

ix. Creemers, B. P. M \& Kyriakides, L. (2016). Critical analysis of the current approaches to modelling educational effectiveness: The importance of establishing a dynamic model. School Effectiveness and Improvement, 17 (3), 347 366.

x. Cronje, G., Du Toit, G. S., Motlatla, M. D. C \& Morais, De K. (2014). Introduction to Business Management. Southern Africa: Oxford University Press.

xi. Edwards, C.H. (2015). Classroom discipline \& management. (2nd ed). Milton, Qld.: Wiley.

xii. Fry, L. W. (2013). Towards a theory of spiritual transformation. The Leadership Quarterly, 14,693-727.

xiii. Fullan, A.K. (2011). Market orientation: Antecedents and consequences. Journal of Marketing, 57(3), 53-70.

xiv. Gerber, P. D., Nel. P. S \& Van Dyk, P. S. (1998). Human resources Management, Johannesburg: Thompson.

xv. Gharehbaghi, K. \& Mcmanus, K. (2013). The construction manager as a leader. Leadership and Management in Engineering, January Issue, 56-58.

xvi. Guoxing, Y. (2007). Research evidence of school effectiveness in Sub-Saharan Africa. Ed Qual Working Paper No 7. EdQual: University of Bristol, UK.

xvii. Hallinger, P. \& Heck, R. H. (2010). Conceptual and methodological issues in studying school leadership effects as a reciprocal process. School Effectiveness and School Improvement, 22 (2), 149-173.

xviii. Hopkins, D. \& Jackson, D. (2003) Building the capacity for leading and learning, in: A. Harris, C. Day, D. Hopkins, M. Hadfield, A. Hargreaves \& C. Chapman (Eds) Effective leadership for school improvement (London, Routledge Falmer). 
xix. Inkoom, A. (2012). Implementation of initiatives to reform the quality of education in rural Ghanaian Junior High Schools. Published Ed.D Thesis, School of Education Faculty of Education and Arts: Edith Cowan University Perth, Western Australia.

xx. Kadingdi, S. (2016). Policy initiatives for change and innovation in basic education programmes in Ghana. Educate, 4(2), 3-18.

xxi. Kerry, T. \& Murdoch, A. (2013). Education managers as leaders: some thoughts on the context of the changing nature of schools. School Organisation, 13 (3), 221-230.

xxii. Kouzes, J., \& Posner, B. (2012). The leadership challenges: how to make extraordinary things happen in organizations. San Francisco, CA: The Leadership Challenge-A Willy Brand.

xxiii. Morant, R. W. (2011). In-service education within the school. London: George Allen \&Urwin.

xxiv. Mulkeen, A, Chapman, D. W., DeJaeghere, J. G., \& Leu, E. (2007). Recruiting, retaining, and retraining secondary school teachers and principals in Sub-Saharan Africa. World Bank Working Paper No. 99. African Human Development Series. Washington DC: The World Bank.

xxv. Newton, E. (2008). School focused staff development: Guide lines for policy maker, London: Falmer Press.

xxvi. Oduro, G. K. T. (2008). Increased Enrolment does not Mean Quality Education (Electronic Version). Ghana News Agency. Retrieved September 10thm 2013m from http: news.myjoyonline.com/education/2008/20151.asp.

xxvii. Preble, L. (2014). Teach Hub' classroom overcrowding: It's Not Just a Number Gamehttp://www.teachhub.com/classroom-overcrowding.

xxviii. Raynolds, D., Sammons, P., De Fraine, B., Townsend, T \& van Damme, J. (2011). Educational Research: A state of the Art review. Paper presented to the annual meeting of the International Congress for School Effectiveness and Improvement, Cyprus, 1-43.

xxix. Raynolds, D. (2016). World Class Schools: Some methodological and substantive findings and implications of the international school effectiveness research project (ISERP). Educational Research and Evaluation, 12 (6), 535-560.

xxx. Saleem, F. (2010). Development of School Effectiveness Model. Journal of Research and Reflections in Education, 4 (2), 166-183.

xxxi. Scheerens, J. (2009). School effectiveness research and the development process indicators of school functioning. School Effectiveness and School Improvement, 1, 61-68.

xxxii. Smith, P. J. \& Cronje, G. J. de. J. (2012). Management Principles: A contemporary South African Edition. Kenwyn: Juta. 